\title{
Girls, Peer Violence, and Restorative Justice
}

\author{
Kathleen Daly \\ Griffith University
}

Address for correspondence

Professor Kathleen Daly

School of Criminology and Criminal Justice

Griffith University, Mt Gravatt Campus

Brisbane, Queensland 4111

AUSTRALIA

office $\quad+61(0) 73735-5625$

fax (0)7 3735-5608

home (0)7 3216-1630

email: k.daly@griffith.edu.au

20 October 2007

Australian \& New Zealand Journal of Criminology (2008) forthcoming

Running head: Girls, Peer Violence, \& Restorative Justice

Word count: 14,300

Please do not quote without the author's permission 


\title{
Girls, Peer Violence, and Restorative Justice
}

\begin{abstract}
Drawing on the South Australia Juvenile Justice (SAJJ) project dataset, this paper analyses youth peer violence ('punch-ups') with a focus on girl-on-girl assaults. My aim is to address and explain significant gaps in the empirical knowledge of gender and restorative justice, and in the aspirations and reality of restorative justice itself. Four points are made. First, of all the offence categories, the male and female punch-ups showed the least degree of offender remorse, positive movement between offender and victim, and victim satisfaction; and they showed the greatest degree of victim re-victimisation and more negative outcomes of the conference process. This occurs because offenders may 'admit' to offending, but deny that their actions are wrong. Second, simple gender comparisons of offender and victim orientations in a restorative process are likely to produce misleading results, unless they are keyed to particular offence categories. Third, for girls' punch-ups, the status of 'victim' and 'offender' is contested, with both protagonists seeing themselves as 'victims' (or as 'non-offenders'). Fourth, although some offending girls say their violence is justified, their female victims are hurt and traumatised, some with significant long-term effects. Implications are drawn for feminist analyses of girls’ violence and for ethical practices of restorative justice.
\end{abstract}




\section{Girls, Peer Violence, and Restorative Justice}

In the last decade, a large literature has grown on youth and restorative justice, although scant attention has been paid to gender-based variation. One aim of this paper is to address a gap in the empirical knowledge of gender and restorative justice, with a focus on girl-ongirl assaults. A second is to explore the gap between the aspirations and reality of restorative justice itself. This gap arises, in part, because advocates have unrealistic aims, participants do not know what is expected of them nor how to act in a restorative encounter, and organisational routines may trump justice ideals (Daly, 2003; see also Trankle, 2007). My research on youth justice conferences in South Australia ${ }^{1}$ shows that it is easier to achieve fairness than 'restorativeness', ${ }^{2}$ sincere apologies are often difficult to achieve, and victims' ability to recover from an offence is contingent, in part, on the distress it caused them (Daly, 2005, 2006). On a variety of measures, I find that assaults between youth ('punch-ups') pose significant problems for restorative justice.

Punch-ups are a fruitful terrain to explore gender and restorative justice. In the South Australia Juvenile Justice (SAJJ) sample of 89 conferences, 26 percent were youth assaults, and in almost all, the victim-offender relationship was male-male or femalefemale. Although the number of cases is small, the data are rich: they contain in-depth observations of conferences and interviews of offenders' and victims' experiences of youth violence and of restorative justice.

\section{RESEARCH LITERATURE}

Four bodies of research are relevant to this paper: practices and research on restorative justice, studies of girls and peer violence, the advocacy and critical literatures on gender and restorative justice, and empirical studies of male and female offenders in a restorative

justice process. ${ }^{3}$ I note at the outset that the literature is remiss in several respects. First, 
analysts often give a sympathetic reading of offending girls' violence and its justifications, and of offending girls in a restorative process, but say little about the effect of girls’ violence on female victims, or of victimised girls' experiences in a restorative process. Second, scant attention is given to the ethical problems that arise when offenders see their acts as justified by something victims did or said.

\section{Restorative Justice: Practices and Research}

Restorative justice has varied definitions and referents (Johnstone \& van Ness, 2007; Sullivan \& Tifft, 2006) and varied practices in different legal and organisational contexts (Daly, 2002a; Dignan, 2006; McCold, 2006). My focus is on diversionary conferences for youth offenders, which is the major form of restorative justice in Australia and New Zealand. In a conference, an offender(s), victim(s), their supporters, other relevant community members, a police officer, and conference facilitator meet to discuss the offence, its impact, and how it should be sanctioned (or 'repaired').

Around the world and with few exceptions, restorative justice practices are set in motion only after a person has admitted to an offence, i.e., they are used in the penalty (or post-penalty phase), not the fact-finding phase of the criminal process. Advocates claim that restorative justice is preferable to established criminal justice because it is a participatory and consensually-based justice, not an adversarial one. The reason that it can be non-adversarial is that it does not adjudicate crime. As we shall see in the youth punchups, offenders may admit to committing offences, but minimise or justify them as having been provoked by victims. This contesting of ‘facts’ sets up an adversarial encounter.

A review of the empirical literature on youth conferences, drawing from Australia, New Zealand, England, and North America (Daly, 2001a, 2002a, 2003; Daly \& Hayes, 2002; Maxwell et al., 2004; Maxwell \& Morris, 1993; Maxwell et al., 2006; Morris \& Maxwell, 2001; Strang, 2001, 2002; von Hirsch et al., 2003) finds the following:" 
- Conferences are rated highly on measures of procedural justice, but are relatively less successful in achieving restorativeness (see endnote 1 for definitions).

- Conferences reduce victims' anger and fear toward offenders, more so than court.

- For offenders, there is a higher degree of perceived procedural justice and restorative justice in conference than court processes.

- Conferences increase offenders' respect for the police and law more than court.

- Victims' sense of restorative justice is higher for cases that went to conference compared to court.

- Most participants are satisfied by the conference process, although the levels of satisfaction are often higher for offenders than victims.

These are general findings, and as such, they gloss over the ways in which specific offences differently affect victims' orientations to a legal process (whether conference or court), their emotions during and after it, and their sense of recovery. Discussed more below, the SAJJ data show that some offences, coupled with offender orientations, cause victims far more distress than others. When offenders minimise offences that cause victims distress, the abilities of offenders and victims to enact ideal elements in a restorative process (e.g., offenders taking responsibility for the offence and apologising sincerely for it) and to experience benefits from the conference process (e.g., reducing victims’ fear and anger) are attenuated.

\section{Gender and Peer Violence}

My review foregrounds girls’ violence toward girls, although I give some attention to boys. Two findings from the literature are pertinent. First, although boys’ and girls’ peer violence may vary, it is condoned and justified by youths as a rational response to behaviour that is perceived as wrong or threatening. Second, feminist analysts differ on the degree to which girls' violence is determined by male power and female subordination. 
Social contexts and elements of violence

Feminist analysts of girls' violence are concerned with bringing girls' accounts of violence to light, and with understanding its meanings, contexts, and motives (Alder \& Worrall, 2004). From conversations with about 100 girls in Glasgow, Burman (2004) and her research group find that girls’ definitions of violence include both verbal and physical behaviour. Thus, when a girl verbally insults another girl, the verbally victimised girl can be transformed into an offender, who feels justified to retaliate with physical violence. Burman (pp. 95-96) finds that girls view physical violence acceptable in responding to verbal abuse in several contexts: to prevent 'continued harassment or bullying'; and to 'strike back in self-defense' when subject to gossip, being called 'a slut' or sexually demeaned in other ways. Other justifications include retaliating for 'stealing a boyfriend' and the need to ‘stick up’ for oneself, friends, or family members (p. 96).

From interviews of 35 girls, all urban and African-American, Miller and Mullins (2006) reach similar conclusions in identifying three situational triggers to girls’ fights: gossip and rumours, including sexual rumours; challenges over dress and reputation; and boys (p. 45). Although these triggers suggest a specifically feminine rationale for fights, Miller and Mullins argue that there are points of overlap with boys' fights. In particular, they find that respect and readings of disrespect are 'central to both male and female conflicts' (p. 58) and that like boys, girls are engaged in 'status contests', i.e., building 'reputations as “tough” and ... not to be “messed with”'.

Lockwood (1997) identifies similar triggers for male and female peer violence. Drawing from interviews of 110 youth (largely African-American, 36 percent female) in two schools in economically disadvantaged areas in the United States, he finds that in 84 percent of cases, the students took responsibility for their actions, but denied that they were wrong. The major justifications that youths gave were retribution (retaliating for perceived harm), compliance (to stop another from offensive behaviour), defence of oneself, and 
promoting one’s image (defending one’s honour and reputation) (pp. 4-5). Lockwood did not show whether the students' justifications varied by gender.

For gender differences in violence, Miller and Mullins (2006: 61) find that girls were less likely to use weapons, their injury to victims was less severe or lethal, and their conflicts were slower to 'escalate to violence’. Like others (e.g., Kruttschnitt \& Carbone, 2006), Miller and Mullins challenge any simple reading of female violence as expressive and relational, and male violence as instrumental. In sum, the literature on youth peer violence, like that for adults, finds that perceived disrespect is an important trigger, and third parties may instigate and escalate violence.

How much do boys matter?

Feminist analysts agree that girls’ peer violence occurs in social contexts of gender inequality and girls’ social devaluation, and that relations with boys play a role in triggering fights. However, some place even greater emphasis on boys and male dominance. Artz (2004: 160) puts the point boldly: 'Girls fight other girls largely to defend their sexual reputations or their connection to a boyfriend ... [whereas] boys fight other boys to establish and maintain dominance within their group ...'. Further, Artz sees girls’ violence as alienated from themselves. This is because girls can only see themselves through a male gaze that 'reference[s] their worth and their range of choice against the standards set by males’ (p. 162). Other feminist analysts, such as Burman, accord girls more ‘agency’ (albeit limited) and may not agree with Artz’s strongly determined view that girls’ violence reflects ‘classic oppressed group behaviour’ (p. 162). For me, Artz’s claim raises an empirical question: is the defence of sexual reputation and connection to boyfriends the major catalyst for girls’ fights? 


\section{Gender and Restorative Justice: Advocacy and Critical Literature}

The advocacy and critical literature on gender and restorative justice is strong on speculation and weak on evidence. One popular claim about gender and justice is that women’s (and girls') orientations to justice use an ‘ethic of care’, whereas men’s (and boys’) use an 'ethic of justice’ (from Gilligan, 1982). The former is said to be associated with relational and contextual reasoning; the latter, with a more abstract sense of rights and rules. In a simplified reading of Gilligan’s (1982) thesis, Masters and Smith (1998) argue that the 'ethic of care' (and women's orientations) can be associated with restorative justice. Their arguments are reviewed and critiqued elsewhere (Daly, 2002a; Daly \& Stubbs, 2006). It is right to say that feminist scholars wish to bring women’s (and girls') experiences and 'voices' more fully into criminological and legal frames, but at the same time, we recognise that analyses of gender and justice must move beyond simple gender dichotomies.

Almost all feminist discussions of gender and restorative justice address the ways in which it may help or hinder female victims of domestic, sexual, or family violence. Few have ventured to consider how it may help or hinder female offenders, or whether there may be gender differences in offenders' orientations to a restorative justice process. Two exceptions are Alder (2000) and Gaarder and Presser (2006). Alder raises these concerns: the generally negative community attitudes toward female offenders may be reinforced in a conference; and offending girls may not want to tell their stories, which may give the appearance of recalcitrance and a lack of remorse. In addition, Alder traces the underlying reasons for a common perception by youth workers that girls are 'more difficult to work with' than boys. She suggests that some girls may be more 'in your face ... feisty, and “difficult” ... [they] may always have been very assertive, independently minded, and “wilful” young women’ (p. 111). The consequences are that those in authority may interpret girls' behaviour as 'uncooperative or lacking the required subservience or 
contrition'. The fact that many offending girls have themselves been victims of physical and sexual abuse may make it difficult for them to engage in a process where a sharp dichotomy is drawn between 'offender' and 'victim' (p. 113). Gaarder and Presser suggest that there is potential for the 'narrative aspect of restorative justice' to give offending girls the opportunity to describe their feelings and participate in a justice decision-making, and that 'dialogue' between offenders and victims may 'reconnect' offending girls 'to their sense of compassion for others by putting them in direct contact with the people whom they have harmed' (pp. 486-487). They also suggest that conferences may be able to address ‘issues beyond the immediate harm caused by crime’ such as victimisation and offending experiences, and family dynamics (p. 489). They caution against encounters between victims and offenders when offenders 'deny wrong doing or express little willingness to change' (p. 489). In such situations, they propose that victims be given other options than having to meet offenders directly.

\section{Gender and Restorative Justice: Empirical Studies}

Like the advocacy and critical literature, the empirical literature on gender and restorative justice has focused on female victims (see, e.g., Cook et al., 2006; Strang \& Braithwaite, 2002). As reviewed in Daly and Stubbs (2006), a handful of studies give some insight into gender-based variation for offenders. My first study of 24 youth conferences in Adelaide, Port Augusta, and Canberra showed that conferences were highly gendered events: few offenders were female, but women were over half of the offender's or victim's supporters (Daly, 1996). In a second study, which reported early findings from the SAJJ data, female offenders were as self-assured as their male counterparts, and they were more defiant and less apologetic for their behaviour (Daly, 2002b). From Maxwell et al.'s (2004) study of New Zealand youth conferences, which had a large sample of 520 youth, most youth held positive views toward the conference process, although girls were less positive (pp. 150- 
151). The girls were also described as less compliant and more challenging of the conference process than the boys; and a lower share of girls than boys said that the conference helped them to reduce their offending, although the post-conference prevalence of re-offending was less for the girls. Compared to the boys, the girls’ profile showed that higher proportions had problems growing up (e.g., experiencing violence and abuse, and running away from home) and had been reported for care and protection; the girls were less likely to say that the police treated them fairly during the police interview or at the conference.

The picture that emerges is that the gap between the aspiration and reality of restorative justice may be even higher for offending girls than boys. This seems counterintuitive in that we might assume that girls are better verbal communicators and have greater interests to resolve disputes before they escalate further; and because girls are generally more law-abiding than boys, they are more compliant with adult authority and behave accordingly. At the same time, several authors suggest that because the socioeconomic profile of offending girls shows even greater disadvantage and victimisation than that of boys, girls may be both more troubled and viewed as 'difficult' (Alder, 2000; Artz, 2004; Baines \& Alder, 1996; Gaarder \& Presser, 2006). These ideas receive confirmation from the sparse empirical literature (Daly, 1996; Maxwell et al., 2004), but there may be other explanations for gender differences or apparently 'difficult’ girls.

\section{METHODS}

\section{The SAJJ Project}

The South Australia Juvenile Justice (SAJJ) project had two waves of data collection in 1998 and 1999 (Daly et al., 1998; Daly, 2001b). The research group, which comprised five female researchers over the two years, and myself as project director and researcher, observed 89 conferences in metropolitan Adelaide and two country towns (Port Augusta 
and Whyalla) during a four-month period in 1998. The sample was selected by offence category: eligible offences were violent crimes and property offences having personal or community victims, such as schools or housing trusts. Excluded were shoplifting cases, drug cases, and public order offences. For each conference, the police officer and coordinator completed a self-administered survey, and the SAJJ researcher completed a detailed conference observation instrument. When a conference had more than one young person or the offence had more than one victim, the SAJJ observations focused on a designated primary offender and primary victim. We sought to interview all the offenders ( $\mathrm{N}=107)$ and the primary victims $(\mathrm{N}=89)$ associated with the conferences. Of the 196 offenders and victims, we interviewed 172 (or 88 percent) in 1998; of that group, 161 (or 94 percent) were again interviewed in 1999. The detailed interview schedules had openand close-ended items. ${ }^{5}$

\section{DIFFICULT GIRLS OR CASES?}

Preliminary analyses of the SAJJ conference observation data showed gender differences in the profiles of 89 primary offenders (21 percent female). The girls were less often remorseful; they were more defiant, and less likely to apologise spontaneously to victims. Were offending girls more 'difficult' than boys?

Analysing the data further, I discovered that the experiences of boys (or men) and girls (or women) in the conference process, whether as victims or offenders, were conditioned by what brought them to the conference. These entry points are crucial in understanding gender dynamics in the conference process and several points later in time. The offence categories of 'violence' and 'property' are not sufficient to grasp these entry points. Rather, I identified seven categories, which encapsulate victim-offender relations, the sex composition of the offence, and whether the victim was personal or organisational. The four violence categories are the youth punch-ups, sexual or physical violence between 
family members, assaults of teachers, and assaults of those unknown to the offender. The three property categories are breaking into or damaging personal property, theft (or attempted theft) of a vehicle, and breaking into or damaging organisational property. Compared to the boys, girls' offence structures contain a substantially higher share of punch-ups and a somewhat lower share of breaking into and damaging personal or organisational property (see Table 1).

[Table 1 about here]

In Table 1, the offence categories are ranked from (1) to (6), which is a ranking from least positive (category 1) to most positive (category 6) on the variables tapping ideal restorative justice processes and outcomes. The ranking was constructed from over 25 variables drawn from the conference observational and victim interview datasets. A clear pattern emerged: the more an offence involved significant injury and personal distress to a victim, but was contested by the offender, the less likely the conference contained elements of restorativeness, offender remorse or accountability, or victim satisfaction, and the less likely a victim recovered a year later. Of all the offence categories, the youth punch-ups scored the least positively on restorative processes. The bi-variate gender difference in offenders' orientations to the conference process now has a partial explanation: girls’ offence structures are composed of a higher share of the offences (in particular, the punchups) that are less likely to evince ideal behaviour in a restorative process. ${ }^{6}$ These findings suggest that offending girls may not be more 'difficult' than boys, but the dynamics of their offences that go to conference may be more difficult to resolve.

\section{GIRLS’ PUNCH-UPS}

My paper focuses on the character of girls' punch-ups by describing how they came about; what occurred in the conference from the perspectives of the female researcher-observer, victim, and offender; and how the victim and offender reflected on their experience several 
weeks after the conference, and a year later. However, readers may be interested in how the girls' punch-ups compare with the boys'. For both, the offenders and victims had different versions of the offence and why it happened; offenders did not feel sorry for what they did, often suggesting that they were also a victim or their actions were fully justified; there were high levels of victim distress after the offence; ${ }^{7}$ and victims felt that offenders were treated too leniently. In only a minority of the girls' and boys' cases did the conference process have a salutary effect. Of the nine girls' cases, four had significant problems; and in two, the victims refused to participate. For just three (or one-third) was there a degree of semi-resolution. Likewise, for the boys: of 14 boys' cases, just five (or one-third) had a degree of semi-resolution. Face-to-face justice encounters can be 'strewn with impediments' (Retzinger \& Scheff, 1996: 317), and these are especially evident in the punch-ups. The following girls' cases show why.

\section{Problem Cases}

\section{Traumatic punch-up}

Of all the female punch-ups, this was the most traumatic for the victim, Jane, who remains haunted and traumatised. She left school because of the continued harassment by the offender, Olivia, and she remains emotionally and physically distressed from it.

'The facts' (case 48). ${ }^{8}$ Jane (15 years) boarded a school bus with her brother; Olivia (13 years) and another girl also boarded the bus. Jane and her brother got off the bus, and Olivia and her friend followed them. The girls began to argue about something Jane had allegedly said. Then Olivia said, 'What's the point of coming all this way without doing something?' She tried to grab Jane’s hair, but fell down. She gripped Jane’s hair, twisting it, and brought Jane to the ground. Olivia kicked Jane in the back and right side several times, and her friend kneed her in the head about six times. Both girls then ran away laughing. During the assault, 
Jane was crying and yelling for help. Later, Olivia admitted to the police that she punched Jane 'pretty hard', but denied pulling her hair. She said that Jane had been saying 'rude things' about her.

Neither Jane nor her parents wanted to attend the conference, and her mother was very angry about the assault. She believed the conference would be a 'waste of time' and 'would push (Jane) over the edge’. Jane feared confronting Olivia: 'I wasn’t really up to it at the time'. Thus, the only conference participants were Olivia and her mother.

The conference was among the most poorly run of all that the SAJJ group observed. The coordinator was unable to control the police officer, who dominated the meeting and lectured Olivia for about 30 minutes. Olivia had not thought about the incident at all; she did not appreciate its seriousness nor its impact on Jane; and she was not remorseful. The conference outcome was to stop harassing Jane for eight months and write a letter of apology.

In her first interview, in 1998, Olivia said that before the conference she was very angry and upset toward Jane. She was less angry after the conference, and upon reflection thought that the conference 'made me think about what I should've done a bit more'. She 'wasn't quite sure what to expect' from the conference, but hoped she wouldn't get community service. The agreement was easier than she expected. She had praise for conferences because 'they're more fair than courts', 'they listen to you', and 'it gives a chance to be treated fairly’. By 1999, Olivia had some degree of contrition for what she had done to Jane. She thought 'it would have been better if she (Jane) did turn up, because umm, we could've sorted it out face to face'. She hoped that with her apology letter she could make Jane feel better 'because I don't want her to go through life scared of me or anything'.

It is difficult to reconcile Olivia's comments with what Jane told us. Olivia and her friends continue to harass Jane: they follow her around school, taunting her by crying out 
'Mummy, Mummy’ because Jane cried out for her mother while she was assaulted. Jane has a high degree of distress because 'the incident' was not a single event, but on-going and persistent bullying by Olivia. She reported that 'I don't want to go to school', 'I'm scared to catch the bus', and 'I'm scared she'll get her friends to get me'. She was very angry toward Olivia, saying that 'she should have talked to me and not done what she did'. Jane then relayed the source of the antagonism: Olivia thought that Jane had written remarks on the toilet wall about her. Jane said she hadn't done this, but felt sorry that Olivia was hurt from it.

In 1999, the SAJJ interviewer said that Jane’s was 'one of the more upsetting interviews. The young girl's life has been completely shattered by this assault'. Jane's physical injuries were still of great significance to her: 'I never had a headache, and now I do. I still get sore eyes; they get blurry and I get dizzy’. She is still bothered emotionally from the assault and continuing harassment. She couldn't accept Olivia’s apology letter because it was insincere: 'she wrote it because she had to and somebody made her. She didn't mean it at all'. If she had to do it over, she would not have gone to the conference: 'I'm scared of her; it would bring it all back'. Although the file shows that Olivia complied with the agreement, Jane was adamant that she had not. However, she was fearful of reprisals if she reported Olivia’s harassment. Jane believed that the agreement was too easy because ‘it didn’t teach her how wrong it was. It was like telling her that after eight months she can come back and do it again. She was laughing about it at school'. The impact of the offence has been enduring for Jane: 'I still have physical problems. ... It changed my life heaps. I'm just scared. I haven’t been out for a year, I can’t see my friends'. She felt even more negative toward Olivia a year after the conference 'because she's gotten on with her life, but I can't'.

The punch-ups with significant or serious physical effects for victims were typically associated with facial scars. The next two punch-ups left victims emotionally and 
facially scarred. The offence contexts are similar: the assaults arose during a party with rumours circulating and amplified by third parties, the offenders were not at all remorseful for their actions, and the victims felt re-victimised with insincere and non-apologetic apology letters.

\section{Shouting in a deaf ear}

The offender, Moira (17 years), said that the victim's side of the story came out in the conference, but not hers. She thought that the victim, Nancy (17 years), provoked the assault by shouting in her ear. Moira has a hearing impairment. Her father put forward this reason, among others, to explain why Moira assaulted Nancy; and this upset Nancy. 'The facts' (case 17). Nancy was at a party, when she heard through a friend (Anne) and others that Moira wanted to assault her. Anne talked to Moira, and she then walked over to Nancy, saying that 'Moira wants to hit you because you're fat'. Nancy laughed at this because she is slim. Some time later, Nancy was walking past Moira, who said she was referring to Anne as being fat, not to Nancy. Nancy brushed this off, saying 'I don't care'. Moira said she couldn't hear because she is deaf in one ear. Nancy approached her and repeated what she said close to Moira's ear. Moira, who was sitting down, kicked Nancy in the stomach, and when she doubled over, she hit her on the head with a bottle. Nancy's ear and cheek were cut, requiring stiches. Anne and her mother took Nancy to the hospital, where xrays revealed that several ribs were badly bruised. About two months later, the police questioned Moira about the incident. She said she had been drinking and had a ‘confrontation’ with Nancy. She didn’t remember kicking her, but did remember throwing a bottle at her.

The conference was held about five months after the incident. Those attending were Moira and her father, and Nancy and her mother. At the conference, Moira was not at all remorseful, although she acknowledged that 'I shouldn't have done it. I know that'. The 
SAJJ observer described her as ‘defensive and a bit hostile' and as having 'little understanding of the consequences of the violence or the trauma to the victim'. An apology was drawn out in the conference, and at her father's suggestion, Moira agreed to write an apology letter.

Moira's father challenged Nancy's version of events and the degree of injury she suffered. He did this twice, which upset Nancy. She expressed her anger about the offence: 'I can't believe that someone would do that to me, when I don't even know them ... that's the scariest thing'. There was no positive movement between any of the conference participants. Although Nancy remained upset by the end of the conference, she held her emotions in check and left quickly. The conference did not help her recover, and her mother thought she needed counselling. Nancy said 'there's nothing I can do to fix it' (the facial scar), and 'I have to live with this for the rest of my life'. She could not accept an apology.

When interviewed in 1998, Moira focused on her side of the story, saying that Nancy

told a different story from me, and I don't agree with her story. ... The police officer just read out her side of the story; he didn’t read out mine. ... And I didn’t kind of hear like half of what he said. But I thought, well, there's no point trying to argue it, but it's best to get it over and done with.

Moira said that Nancy 'didn’t suffer as much as she acts. She wanted me to suffer more than I should. I don’t believe she had stitches'. After hearing Nancy’s story, Moira said 'I was a bit pissed off because I didn’t agree with her story. ... I think she was crapping on the whole way through, basically, pouring it on'. She thought the agreement, which was to write an apology letter to Nancy, not to harass her for four months, pay \$16 in compensation, and attend a counselling session was 'too easy'. She expected to get community service or fines. 'Community service, I didn’t get that, thank God. I wouldn't 
have liked to do it, to give up my weekends'. She was still a bit angry toward Nancy because 'stuff she says about me these days, gets back to me. It's crap. I wouldn't want to talk to her or look at her'. She was satisfied with how her case was handled and had a positive view of conferences mainly because 'it's better than getting a conviction thing against your name’.

During Nancy’s 1998 interview, both parents were concerned for their daughter and hovered during the interview. Her father signed the consent form and went to another room, but came back to sit at the table during the first part of the interview. Her mother also came in and stayed for the remainder of the interview. Nancy was angry about the agreement and Moira's lack of compliance, and her interview responses focused largely on these elements. Moira’s apology letter was late; it was typewritten, not signed, and had little feeling. The $\$ 16$ in compensation had not been paid. Without question, Nancy felt re-victimised:

When we got the letter, she hadn’t even signed it. It was meant to be delivered to me within a week, and it got here like two weeks after the date ... And it made me even more mad because like (the coordinator) actually asked her like how long would you need to do that.

Nancy's parents were disappointed with the conference process, the lack of follow up, and insufficient information given to them.

Nancy's physical injuries were of great significance to her: 'she scarred me for life, really', the reference being the cut on her cheek and ear, which required stitches. She wanted Moira to know that 'she’s got problems that she should learn to deal with'. About the conference, she said 'I just know that it wasn’t really fair what did happen’, again referring to the agreement, which she thought was too lenient. 'What's writing a letter saying sorry and having to pay $\$ 16$ ? What kind of lesson is she learning from that?' Nancy was 'mad and upset' when she heard Moira’s account of what happened. 'She tried 
to make it sound like, because she'd being having troubles with some girls that I know, that it was their fault that she hit me ... She twisted it ...' In addition, Moira's father had minimised his daughter's behaviour. 'Her Dad blamed the offence on her disability. They talked about disabilities for a long time'. Nancy was not at all satisfied with how her case was handled, and she left the conference upset both by the offence and what occurred in the conference. Her attitude toward Moira remained negative: 'I don't think anything she could have really said would have changed my opinion’. She held generally negative views of the conference process, saying she wouldn't go to one again because 'it was a waste of time’.

In 1999, we were not successful in interviewing Moira or Nancy. For Moira, after we tried more than ten times to make an appointment and after one had been confirmed, but she didn’t turn up, she was classified a non-respondent. For Nancy, we made several efforts to reach her; but in each case, we were only able to speak to her parents, who said she'd call back if she was interested in being interviewed. In the last phone call, her father said 'what's the point? It was a shambles'. He was critical of what was agreed to in the conference and Moira’s lack of compliance. 'We never got the money, and the apology letter came a month late and wasn’t signed'. 'It was a complete waste', a comment he made many times during the phone call. He said that we shouldn't interview Nancy because 'it would bring it all back again', ... and she wants to just get it behind her. She doesn't want to think about it'.

\section{Female honour and sexual reputation}

Like the last case, this assault occurred at a party with rumours flying, aided by third parties. This case differed in that the offending girl's sexual reputation was at issue: the victim allegedly called her a 'slut'. The offender, Britney (14 years), believed her actions were fully justified, even more so than Moira. Reinforcing the findings from Burman (2004) and Lockwood (1997), Britney believed her assault was authorised by the values of 
her generation, pointing out the 'different thinking' of people in her age compared to those in 'the system'. She explained it this way:

They're different generations ... Like if I went and told the story to one of my friends, which I have, they’d just go, 'she deserved it', because that's the way it is. Like, you might not think that's the right thing to do, and the system might not think so, but in my generation, with my friends and everything, it is. I won't take shit. I've put up with it for many years, and I'm sick of it. She got what was coming to her, and let's hope it teaches her a lesson.

Britney’s only regret was that she 'made the mistake of hitting a wuss', who reported the assault to the police. As a result, she said 'I'm a little more careful with who I punch heads in with'. The victim, Patsy (14 years), 'felt really upset’ by the apology letter, which she received a day before I interviewed her in 1998. 'I felt that she accused me of being in the wrong, and that it's my fault, I caused the problem myself'.

'The facts' (case 59). Britney and Patsy were at a school social. There were rumours that Britney said she 'felt like bashing someone up', and some people were saying that Britney was a 'slut' and a 'bitch'. Patsy agreed that this was what some people were saying, but she said that she didn’t call Britney these names. Patsy was standing with friends when Britney confronted her about whether she had been calling her names. Patsy said she didn’t and tried to move away. Britney then grabbed her and punched her in the face with her fists, cutting Patsy's face with her rings. The next day, Patsy went to the clinic; she had a black eye, injuries to her ear, and bruising to the neck. Some time later, she found that her eyelid was damaged and looked droopy. It was uncertain if it could be fixed. More than six months elapsed from the incident to when the police spoke with Britney (the reason for this delay is not clear, but it may be related to Britney's pending court case, as described below). Britney's explanation for the assault is that Patsy called her a 
'slut'. She added that she had had 'a bad day' and wasn't in any mood 'to take shit' from people. She believed that Patsy was jealous because Britney was with a male friend of Patsy's, and this was why she was calling her names. The police report said she was 'sorry for her actions', and recommended a family conference because 'it will give the accused an opportunity to apologise to the victim and make her accountable for her actions'.

The conference was held about seven months after the incident, and contrary to the police officer’s expectations, Britney neither apologised nor was made accountable for her actions. Attending the conference were Britney, her youth worker, Patsy, and her parents. Before the conference began, Patsy was nervous about meeting Britney; and during the conference, she was very quiet. By contrast, Britney was confident, self-assured, mature, and well-spoken.

Although there were many openings, Britney offered no apology to Patsy, and there was no positive movement between them. Both girls disbelieved the other's story, but neither pressed each other about it. Patsy's mother did most of the talking for her daughter, and over time, Britney became increasingly defiant. There was a long break when Britney was supposed to discuss the agreement with her social worker, but they discussed other things. The agreement, which was to have Britney work at a nursing home, where Patsy's mother works, seemed a bit restorative on the surface. A good deal of time was taken in deciding how many hours Britney should work because Patsy and her parents did not know what was appropriate; they ended up agreeing to eight hours. In addition to the frosty relations between Patsy and Britney, the coordinator and police officer also had problems communicating with each other. None of the expected benefits of the conference process was apparent, despite the efforts of the coordinator and Patsy's mother. 
When interviewed in 1998, Britney was clear on what happened that night she punched Patsy:

She lied. She did call me that (a 'slut') to my face. I knew it, and she knew it, but I don't think she wanted to say anything in front of her parents ... That's the only reason that I hit her. You think I just go around starting on people? I'm not like that. You have to do something to get me angry. It's just a simple fact. She said that Patsy's account of what happened made her angry because 'she lied about it. ... She said she didn’t provoke me'. When asked if she was surprised about anything that Patsy said, Britney minimised the impact of her violence: 'What surprised me was, if she was that beaten up, why would she want to go to school the next day, why didn't they take her to the doctor straight away?' She felt unfairly treated by Patsy: 'I could see her grin. She was laughing at me because I got into trouble, and she started it'. She thought the agreement was fair and very easy:

Because it was not a very harsh punishment, and I was happy with it when I left ... I didn’t have a problem with it.... Only eight hours community service, like one day. [And did you have to do an apology?] Yeah, a written apology. Only like one sentence. [Really? Was it half-hearted?] I just said, 'I'd like to apologise for what happened that night, you and I both know the truth, maybe you can take it into consideration'. I wasn’t threatening her, I wasn’t rude about it.

Britney assumed she would be asked to pay compensation, and she thought she would get more hours of community service. 'I didn't actually think about how much I'd get until I heard about all that crap with the cat-scans and all that, x-rays, like "oh, God”". There was no link in her mind between the eight hours of community service and making things right for her and Nancy.

Several months after the 1998 interview, Britney was in court on charges related to a police raid on her mother's house, which occurred about a month after the SAJJ assault, 
but before the SAJJ conference. Britney was caught with a substantial amount of money (she said AU\$60,000) as she attempted to leave the house. One offence was proved, and she had to pay a fine and court costs. Some time later in 1998, her mother was prosecuted on drugs and weapons possession charges, convicted, and sentenced to serve time in prison.

When I interviewed Britney in 1999, her mother had more than two years remaining to serve in prison; and Britney was visiting her weekly. Although now just 15, Britney lived in her own apartment, where 'I get heaps lonely and miss my family'. What she remembered most from the conference was 'that Patsy girl lying. That's all I can really remember ... telling a story that both she and I knew was not true ...'. She said that the reason she agreed to write an apology was 'truthfully, just to get me off'. She wasn't at all sorry for the assault and felt she was pushed into writing the letter. At the same time, she said 'I know what I did was wrong'.

Four things were uppermost in Patsy’s mind in the 1998 interview: Britney’s insincere apology letter, what actually happened on the night of the offence, regret that she and her parents had asked for too few hours of community service, and the effect of the assault on her facial appearance. Patsy and her parents were upset with the apology letter, and they had been in touch with the conference coordinator about its quality and content ('it was a joke and an insult'). Patsy and her parents came to the view that the number of hours of community service was insufficient because of a comment the police officer made. At the end of the conference, Patsy recalled that 'he said that if this was his case, he would have given her 25 hours community service, and we only got eight because neither me nor my parents knew what time would be satisfactory without being too harsh'. Finally, there were major concerns about nerve damage to her eye and the likely high medical costs if a specialist was required. Patsy wanted to be clear on what actually happened that night: 
She said that I went up to her and said she was a slut, or that she came to me and asked what did I say, and I said, 'a slut'. That shocked me because I'd heard that from seven or eight different stories, so I was pretty much shocked. [So you were shocked because that's not how you remembered it?] No. ... [Just so I know ... Your understanding is that you didn't say 'you are a slut', but you said 'some people are saying that you are', and that is an important difference for you.] Yes. [OK, so that is the point where your stories seem to differ.] Yes, 'cause I could see, if I did call her a slut, I could see why she would bash me because not many girls like to be called that. And I mean I wouldn't. I said it the way I said it, which is I never called her a slut.

The difference between saying ‘some people are saying you are a slut' (Patsy’s memory of what Britney said) and 'you are a slut' (Britney’s memory of what Patsy said) was significant for both, and it created allegations of 'you're lying' by both girls.

Patsy was anxious about seeing Britney at the conference: 'I was really frightened that she was going to lash out at me'. Her attitude toward Britney was negative and did not change as a result of the conference. When asked why, she said 'Just her attitude. She seemed to me and my parents as if she had to go there so she just went ... She didn't seem to care at all about what happened’. Despite her many criticisms, Patsy said she was satisfied with how her case was handled. Her reply raises questions about what 'being satisfied' means for a crime victim, but in her case, it appears to be an ability to participate in a face-to-face encounter, even if she said very little, was insulted by the apology letter, and thought the outcome was too lenient.

In 1999, Patsy’s views on both the conference and Britney remained consistent. She believed that Britney was not at all sorry for what she did and was pushed into writing an apology letter. Her eye lid injury continued to bother her. 'I keep getting questions about why is your eye like that? [Can you show me what happens?] The lid comes down 
a bit and the eye looks smaller'. During the interview, Patsy showed me what the problem was, and I compared her eyes. There was a droop, although subtle and imperceptible at first glance. Patsy has had and will have considerable out of pocket medical expenses to tighten the muscles around the eye: her mother phoned the SAJJ office to report the current amount was $\$ 2,000$ several weeks after the interview. They are pursuing a criminal injuries compensation claim.

Patsy had lingering emotional effects from the incident and had not fully recovered from it. The main reasons were the apology letter, 'it was a slap in the face basically saying it was my fault for me getting bashed', and on-going problems with her eye, 'we don't know if it can be fixed, or if it's going to be worse'. The incident affected her mother, who has become more protective of her and restricts her social activities. Changing her view from 1998, she said she wished her case had gone to court, rather than to a conference 'because the way she treated the punishment, I preferred court'.

\section{Deep-end offender}

In this inter-racial assault, the offender, Terry (14 years and Aboriginal) has been in trouble with the police many times, both before and after the SAJJ case, mainly for theft. She had already attended two conferences as an offender on the day we observed her, and the SAJJ case was her third. (This is not a recommended conference practice.) She and the victim (Anita, 14 years) had sharply different accounts of the conference process. While Terry is entirely negative, Anita commended it, saying that it had a positive impact on her, and hoped that it did so for Terry.

'The facts' (case 82). While at school, Terry came up behind Anita and stepped on the back of her heel. She apologised, but then did it again. Anita turned and said, 'Stop it, go away', and Terry punched her in the face several times, took her glasses and threw them in the bin, and hit her again. A teacher intervened and stopped Terry. That evening, while Anita was at work, a person continually rang, asking 
for Anita. After a while, she took one of the calls; it was Terry, who 'was being very aggressive' and said 'you stupid bitch'. Later in the early hours of the morning, there were more calls to Anita's home: the phone would ring, and when Anita's parents answered it, the caller hung up. Terry says that Anita hit her first, but she did admit to hitting Anita after throwing her glasses in the bin. The police say that Terry has 'no contrition for her behaviour. She seems to think she can do what she wants'.

The conference was held two months later. Attending were Terry, her mother, Anita, and her mother and stepfather. The SAJJ observer described Terry as 'sullen and unresponsive ... She doesn’t want to be here, doesn't want to be told what to do'. She showed little remorse because she believed that Anita provoked the assault. Terry had apologised right after the incident in school; for this reason, she offered no apology at the conference. Terry’s mother was highly critical of her daughter's attitude and behaviour. There was no positive movement between the two girls although there was between the parents. The conference unravelled during the discussion of the agreement. Terry had not been attending school, and part of the outcome was for her to attend a learning centre four days a week for ten weeks. She did not want to sign the agreement, but relented after being pressured by everyone at the conference. She couldn’t wait to get out of the conference room and was crying when she left.

The researchers who interviewed Terry in 1998 and 1999 said it was difficult to conduct the interviews. In 1998, the researcher said it a 'nightmare interview. She is a nasty, angry kid ... extremely uncooperative and disinterested, rude and offhand'. In 1999, a second researcher noted 'this interview was most difficult because the most that the young person would say was “I don’t know” and "nuthin”. Apart from these words, “fuckin” was the most commonly used word'. 
Terry felt unfairly treated by the coordinator (who was Aboriginal): 'He’s a bastard. He made me sign the contract. I had no choice'. While she thought that Anita treated her fairly, Terry did not feel at all sorry for her, nor was she affected by what Anita said at the conference:

She's probably making it up. [You thought she was lying?] Yeah, probably. As if that's true. Crap. [But you didn’t argue the point at the conference?] Nuh, couldn’t be stuffed. [Did she say anything that surprised you?] Yeah, she was saying that she was actually shaking and all that. [Afterwards?] Yeah, that was crap, bullshit.

Terry 'didn't care about' the conference and was not at all satisfied with it. She was most critical of the agreement, which she described as too harsh and very unfair because 'they made me go to that crap school. [The learning centre?] Yep. [And you've been and don't like it?] Nuh'. She said that both the police officer and coordinator lectured her too much, and that she was pushed into things she didn’t agree to. She said it was unlikely she'd get into trouble again because 'I'd probably have to end up going to that dumb school'. (She was involved in six separate incidents in a ten-month period after the SAJJ conference.) All her views of conferencing were negative: 'they’re crap' and 'it’s a waste of time'. Her negative views largely centred on the coordinator's 'making me go to that school'.

In 1999, Terry said she remembered little from the conference. She didn’t want to apologise because 'it wasn't my fault'. She completed the agreement, but she did so only to avoid going to court. When asked about why she got into trouble again after the conference, Terry said she didn’t know why, but among a list of reasons provided, the one she selected as most important was that 'it's fun'. She thought that while the conference process was more fair and she had more of a say, it was more of a joke than court. Neither conference nor court made her think twice about re-offending. 
In 1998, Anita reported a more positive experience with the conference process than Terry. Although Anita's physical injuries were only a bit significant to her, she had a high degree of emotional harm after the incident. She 'avoided' Terry and was 'scared to be around her'. She felt negative toward her before the conference, but she felt positive after, citing the process and meeting Terry's mother as the main reasons. She hoped that the conference would 'sort out Terry's life and the problems she's got'. She hadn’t thought about what she wanted to say to Terry before the conference ('I didn't want to talk with her'), but she was concerned that Terry would 'get mad and everyone would gang up on her' at the conference. She felt sorry for Terry because she was 'young and in so much trouble', and she thought it likely that she would get into trouble again because of 'the sort of person she is'. Anita praised the conference process as 'good and helpful' and thought that victims could gain 'their peace of mind' when meeting offenders.

In 1999, Anita continued in a highly positive vein. She had no lingering emotional harm and had recovered from the incident: 'It wasn't a big deal to me'. She still felt positive toward Terry because 'I've seen her a few times, so probably that's helped. [How has that helped?] Because I've talked to her, and I'm not really bothered by it anymore'. She was glad to be at the conference 'so I could have a say, and I saw everything that happened'.

While Anita's experience of the conference was positive, for Terry, it was just the opposite and a total waste of time. Compared to other girls’ punch-ups, the offender and victim were the widest apart when judging the conference process and impact. Terry’s mother believed that a conference 'wouldn't work and would be a waste of time' for her daughter. Is Terry a 'difficult' girl or something else? She was angry, had little respect for adult authority, and enjoyed the fun of lawbreaking. 


\section{Semi-Resolution and Positive Change}

Three cases showed that a degree of semi-resolution and positive change can come from a face-to-face meeting. The victims were relatively less affected by the assault, physically and emotionally, and the offender and victim wanted to put the incident behind them. Two cases are presented. ${ }^{9}$

\section{'Sort-of' friends}

In this case, the girls had been friends for three years, and the victim, Eve (12 1/2 years) tried hard to bring the offender, Susan (about to turn 13), around during the conference. The police report suggests that their relationship is 'an on again, off again affair, with problems caused by rumours and allegations'. It also notes that the girls' parents 'seem to have a bit of animosity toward each other as a result of the girls carrying on'. Despite this, it came out in the interviews that the girls, especially Eve, wanted to resolve their problems and be 'sort-of' friends.

'The facts' (case 61). Eve approached Susan on the sidewalk outside school, requesting that she ask the school bus driver to wait for another person. Susan called Eve a 'bitch' and started punching her. She hit her in the back and Eve bent forward trying to get away. When she did this, Susan grabbed the back of her hair and pulled Eve around by the hair. She continued to punch Eve in the back and kicked her in the right knee. A police officer observed the fight and intervened, saying that it was 'totally one-sided, and at no time did Eve hit Susan or defend herself'. Eve was very distressed and crying so much that she had trouble catching her breath; she was too fearful to take the bus home, so the police officer gave her a lift. She had a sore back and a lump on her forehead. Susan's version was she thought that Eve was going to walk into her, so she pushed her away. She said that Eve punched her and they both started punching each other. Susan said she wanted 
to talk with Eve about things she was saying about her, calling her names and 'spreading secrets'.

The conference was held two months later. Attending were Susan and her mother, Eve and her father. The observer described Susan as 'hard as nails': she was not at all remorseful, a little defiant, and didn't want to apologise. Eve was effective in describing the story, saying 'I was heaps scared, and inside me was all shaking'. Eve wanted to be friends again, but Susan was unmoved, even when Eve cried. Susan's mother said that her daughter had planned to apologise and give Eve a hug during the conference, but the discussion put her under some pressure, so she didn't. There was little positive movement between the girls, but there was between Susan's mother and Eve's father. After the conference was over, the parents and the girls left talking and laughing. Susan's mother said to Eve's father that if ever there was any trouble, to let her know.

Despite what appeared to be an unmovable offender, Susan's interview revealed that the conference had a salutary effect on her. She said she was 'kinda looking forward' to the conference so 'we would be friends again'. Listening to Eve’s story had a major impact on her. 'Some of the things she said made me feel like really bad and stuff and like made me want to be her friend again’. She said she felt very sorry about Eve after the conference was over: 'She's changed a bit, and most of what she said at the conference made me feel sorry for her'. She was satisfied with how her case was handled, and she said it was unlikely she'd get into trouble again because she didn't want to jeopardise her chances of becoming a lawyer.

Eve's physical injuries and emotional harm were moderately significant to her. Before the conference, she was 'heaps angry' and 'heaps scared' of Susan. One thing she hoped wouldn't happen was 'to see Susan cry. I sort of care for her still, she was my best friend. [Why didn’t you want to see her cry?] I don’t know; if I see anybody cry, even people on the street crying, I start crying'. She said that Susan's story had little impact on 
her because 'what she said in her statement ... was so untrue'. Susan said to the police that she said to a friend, 'hold my books, I'm going to talk to Eve'. But Eve said a witness heard her say, 'hold my books, I’m going to smash Eve’s face'.

Eve thought the agreement was fair, though a 'little bit easy'. (Susan only had to apologise at the end of the conference.) 'There was no point keeping enemies. Like I don't want to be her friend or anything, but I don't want to be her enemy'. Her attitude toward Susan shifted from negative to a bit positive. Her reasons were that Susan showed remorse and ‘now she avoids me, doesn't talk to me, just says hello, and doesn't cause trouble'. Eve's comments give us an insight on what a resolution with Susan would be: not close, but not fighting either. She was satisfied with how her case was handled and had high praise for conferences: 'you do get, like a good result and stuff, and they do get a punishment'.

In 1999, the SAJJ researcher had difficulties eliciting responses from Susan, and some responses were contradictory. For example, when asked why she said sorry, her response was 'cause I had to. I didn’t mean it'. Then, she said she definitely wanted Eve to know that she really was sorry. She was close to tears about 20 minutes into the interview when asked about how others think of her. It then became clear why she was upset (and perhaps giving inconsistent answers): her mother had recently reported her to the police for smoking marijuana in her bedroom.

In her 1999 interview, Eve believed that Susan’s apology was not sincere, that she apologised to get off easier, and was not really sorry. However, Eve is not bothered today by the assault and has no lingering emotional problems. She feels positive toward Susan because 'she doesn't bitch as much'. They still see each other at school and on the bus, and they occasionally talk to each other and are 'sort-of' friends. She thought the conference resolved their problems 'a little bit' and remains satisfied with how her case was handled. 


\section{Name calling and apologising back}

Compared to the previous case, this case shows that a more positive conference can occur when a victim's injuries are not serious or does not have lingering effects, and an offender does not minimise the harm and is apologetic. It also shows that other events, far removed from the legal process, can affect a youth’s maturity and outlook.

The 'facts' (case 81). The victim, Karen, and the offender, Liz (both 14 years) were at a teen social club. Liz called Karen a 'slut' and threw a can at her. Karen said, 'speak for yourself'. Liz bit her wrist, then grabbed her and punched her in the mouth. As she was leaving, Liz said, 'get anyone on to me, and I'll bash your head in’. Both before and after the incident, Karen had been harassed by Liz and some of her friends. Liz called her a 'slut' and a 'whore', waved her fist at her and gave her the finger. She claims that Karen called her a 'slut' first. Some months before, Karen witnessed Liz’s friends hurt an elderly man; and the police think that Liz is trying to intimidate her.

The conference, which took place in the country town of Whyalla, was convened about five weeks after the incident. Before the conference began, Karen, Liz, and their mothers were standing outside the community hall. The two girls did not speak to each other, and neither did their mothers. This seemed an inauspicious start. However, during the conference, the mothers communicated well with each other, while their daughters were quiet. Liz was a bit remorseful for her actions, although an apology had to be drawn out. She was generally non-communicative and a bit sullen, although cooperative. As the conference proceeded, there was some positive movement between her and Karen, when both apologised for what happened. Both agreed to try to stop the negative behaviour, although there was some wariness between them. There was stronger positive movement between their mothers, the SAJJ observer noting that the 'Mums ran the show a bit'. Although the conference itself did not evince a high degree of restorativeness, especially 
between Liz and Karen, a year later the matter was closed for both of them, and they had positive memories of the conference moving them along.

Two themes emerge from Liz's interview in 1998. First, she felt that the conference was unfair because

I couldn’t say what I was thinking. And I know that most of the story that Karen said was a lie, but I still had to apologise ... Her story wasn’t even the truth. So I couldn't even say to, ask her why she lied or anything, 'cause I'd get in trouble. I don’t think it’s very fair.

This comment explains why Liz was quiet at the conference, and it reflects the belief held by all the punch-up offenders that their victims were not being completely truthful about what happened, but that it was better not to challenge the victim's story or police officer's report. A second theme, which is unusual for many punch-up offenders, was that Liz felt ‘kinda very sorry’ for Karen. When she heard Karen’s story, she ‘felt more sorry for her, I s’pose. I felt bad. [Could you tell me why you felt bad?] For actually hitting her'. She said she 'kind of learnt my lesson. Kind of learnt how I would feel if it was the other way around'. The mutual apology that occurred in the conference was important for her. When asked about the degree of importance of apologising to Karen, she said, 'It was kinda in between. It was important, but it was more important because she apologised back for what she did'. Liz was positive toward the conference process because 'instead of just getting in trouble ..., you kind of get to sort things out as well'.

Karen’s account of the offence differed from Liz’s. Whereas Liz maintained that Karen started the name calling, Karen said it was the other way around. And although Karen said she was satisfied with the conference and thought the agreement was about right, she left the conference upset by what Liz said 'because it all came back to me as if I started it, like name calling and stuff'. Her physical injuries were not of much significance, and she had a low to moderate degree of distress from the incident. Her 
attitude toward Liz shifted more positively, and she credited this to Liz's willingness to make things right and to her ability to tell Liz how she felt. She was positive toward the conference process because you can 'get to the bottom of the problem and sort it out'.

When I returned in 1999 to interview Liz, I saw a transformed, mature young woman. In the past year, her mother has been sick with cancer, having been diagnosed about five months after the 1998 interview. While Liz's mother was in an Adelaide hospital, about a five-hour drive away, Liz had to look after herself. She decided to do better in her school work 'to make my mother proud of me'. She received all A's on her report card, whereas in the previous year, she had 'mucked around' and didn't do well. When her mother returned home from the hospital, Liz cared for her and ran the household, cooking and cleaning. She was confident and self-possessed. When she recounted what had occurred over the past year, how she felt toward her mother, and her sense of accomplishment and pride, I was moved emotionally.

In the sequence of questions about the apology process, Liz's answers seemed to be contradictory, but upon reflection, they revealed the subtleties and nuances of the apology process in the punch-ups. Liz began by saying she said sorry 'because if I didn't, I'd just get into more trouble'. She wanted to let Karen know that she was really sorry, but at the same time, she felt pushed into it. Ultimately, she said that while 'I felt pushed into it, I would have said it anyway’. She hoped that in saying sorry, she could make Karen feel better “cause, you know, she doesn’t feel safe walking around, and I know how uncomfortable it'd be'. Saying sorry made her feel better 'because it kinda took a load off my chest. I don't walk around every day punching people'. The agreement, which was a three-month good behaviour bond ${ }^{10}$ and a conference verbal apology, was about right, although 'it should have been a bit harder'. Liz stayed out of trouble in the year after the conference, in part because she decided she just wouldn't get into trouble, and in part, because she understood its negative impact on her mother. 
In 1999, Karen said she had fully recovered from the incident and had no lingering physical or emotional problems. She attributed her recovery to the fact that 'we both acted like adults and put it behind us'. She cited the conference process as the most important element in helping to put the offence behind her. She believed that Liz was really sorry, and this made Karen feel more positive toward her. It was more important to Karen that she received a genuine apology rather than Liz doing work or paying money because 'her paying for it wouldn't like pay for what she's done sort of thing. [Can you say more about what you mean by that?] It just doesn't repair what she has done. [So tell me why the money doesn’t matter?] 'Cause it was a physical thing and didn’t have anything to do with money'. Karen's comments alert us to the different contexts when an apology, by itself, may or may not be sufficient for victims. For her, there was no nexus between the assault and Liz paying money or doing work. Rather, the vindication of the assault would come largely (although perhaps not exclusively) from an offender’s apologetic position.

Of all the youth punch-ups, Liz and Karen's case was exceptional in being the only one in which both definitely agreed that the offender was really sorry. Theirs was an unusual punch-up in that some of the ideal elements of the conference process and outcome were present.

\section{Family Conflicts and Harassment}

In the following cases, the assaults were part of on-going conflict between the girls and members of their families. Both took place in Port Augusta and involved Aboriginal girls; and for both, the victims did not attend the conference, nor were we able to interview them. ${ }^{11}$ There is no indication that the conflict continued, but because the victims (and their family members) refused to participate in the conference process, there was no semiresolution to the conflict either. 


\section{Sticking up for family}

Although the assault occurred in Port Augusta in July, at the time, the offender, Roxanne (17 years) could not be located for police questioning. She was reported in October when the police arrested her on 'other matters'. She made no admissions to the police, and the case went to court in December. It was in court for six months before being referred to a conference, which was immediately scheduled in June, nearly a year after the incident.

'The facts' (case 87). Late one Saturday evening, the victim, Kathy (17 years) was leaving a club and about to get into a taxi. Roxanne called out her name, and she went back toward her. When she did so, Roxanne started to pull her hair and then she punched Kathy in the face three or four times, saying you are a 'fucking slut' and a 'slut'. The assault continued even as Kathy tried to get into a cab. Another person, a male, approached and punched her. He was arrested, but Roxanne could not be located.

Kathy now lives in Darwin (about 2700 kilometres north of Port Augusta), but comes to Port Augusta from time to time. She and her mother are well known in Port Augusta as trouble makers. The police officer who attended the conference told us privately that Kathy's mother is a 'town psycho', who verbally and physically abuses people, and threatens them with knives. Neither Kathy nor her mother could be located to attend the conference, nor could we locate Kathy for an interview.

Those attending the conference were Roxanne, her parents, and her young brother. Roxanne was observed to be well-spoken and cooperative. During the conference, she said she was sticking up for her family, who had been victims of phone calls and harassment from Kathy's mother. When describing these stories of harassment, taunting, and racial insults, she became quite distressed. Roxanne's parents had little involvement in the conference: her mother left early with her son, and her father had little input. 
When she was interviewed in 1998, Roxanne's main concern was to 'get this (conflict) all over and done with'. Her experience at the conference was positive, and the agreement was a lot better than she expected. She agreed not to commit an assault in the next three months, although she added that 'it's not too easy to stay out of trouble'. About Kathy, Roxanne said, 'I don't like her'; and she thought that 'things would have been worse' had Kathy attended the conference. She was unsure if it was a good idea that offenders meet victims.

In 1999, Roxanne’s views toward Kathy’s being at the conference changed. 'It would have been good to have her there... So I could have apologised and told her why I assaulted her. [Why did you?] A bit of an argument between me and her mum'. She would have wanted to apologise 'more or less, so I could just get it off my chest that I had apologised, and that I knew that I shouldn't have done it'. She believed that a conference '... helps more than court would. ... With court it's just straight in and out, and they don't do much talking and explaining'. She has gotten into trouble in the past year because of 'a disagreement with me and my friend'. She thinks she needs to 'move away from Port Augusta' to stay out of trouble because there are 'people who dislike me'. When asked why these disputes come about, at first she said she didn't know why. Then, she said that people were asked by others, including family members, to carry out 'pay back', and this is partly what draws her into fighting. In 1999, Roxanne was enrolled in a public health course, and in 1998, Kathy was enrolled in tertiary course in Darwin. These young women were stable working class young people with aspirations. They were drawn into fights and fighting for similar reasons as the non-Aboriginal young people (i.e., responding to taunts and harassment by others), but they may also be brought into wider family disputes. Smelly jacket

This apparent trigger for this assault was that Kayleen, the victim (13 years), was alleged to have said that the offender's jacket smelled. But, as we look more deeply into the 
offence, we find that it arose from Kayleen's history of teasing and harassing of the offender, Jackie (15 years), and other kids at school. The coordinator spoke with Kayleen's grandfather when preparing the conference. He said that she was not coming, and the family wanted nothing more to do with it. He was described by the Aboriginal coordinator as 'quite aggressive’.

'The facts' (case 86). While at softball practice one evening, Kayleen was approached by Jackie. As Kayleen recalled in her police statement, here is what was said:

Jackie: 'When Sue was wearing my jacket, did you say it smelt?' Kayleen: 'No'.

Jackie: 'Yes you did, so don’t lie'. Jackie then punched Kayleen six times to her lip and behind her ear. Kayleen sat down to stop Jackie from punching her. Jackie then slapped her with an open hand to her face, saying 'If you keep getting cheeky, you better look out'. Kayleen went home and called the police; they took her statement right away. The police went to Jackie’s house, questioned her, and reported her for the assault.

The police wrote to Jackie’s mother, inviting her to attend the police station with her daughter for a formal caution. There was no response to the letter, and the matter was referred to conference, which was held in June, about three months after the incident. Attending were Jackie, her cousin (an adolescent), and a youth worker. Jackie said her assault was provoked by Kayleen; and although she seemed to be remorseful for her actions, she would not send an apology letter or say sorry to Kayleen. She was tired of Kayleen hassling her.

When interviewed in 1998, Jackie said she didn’t know much about the conference process. 'I didn't know the victim was supposed to be there. I thought we would be in separate rooms'. She hadn’t thought about what she might say to Kayleen, but she was 
sure that she 'didn't want to sit in the same room as her'. For the agreement, Jackie was not to be reported for another assault during the next three months and to enrol in counselling for anger management. She believed the agreement was very fair, and it was a lot better than what she expected.

Like Roxanne in the previous case, Jackie's replies to the presence of the victim changed over time. In 1998, she said, ‘I don’t think the offender and victim should be in the same room. [You don't think the victim should ever be there at the conference?] No, they shouldn’t ever have victims there'. She said the opposite in her 1999 interview. 'It would have been good (to have Kayleen there). She done the assault so she should have been there. [You mean she assaulted you first?] No, I assaulted her. She put me in for the assault'. Had Kayleen attended the conference, Jackie said she would have apologised 'because I shouldn’t have assaulted her', but there is another reason Jackie wanted Kayleen to be there. Because 'she put me in for the assault', Jackie believed that Kayleen was obligated to attend.

Jackie finished the agreement '‘cause I wanted to be good,' but like Roxanne, she said doing so didn’t make things right for her and Kayleen. She got into trouble in the past year for another assault. When asked why, she said the victim 'was like talking about me. Saying things that wasn't true'. When asked what would have to happen for her to stay out of trouble, Jackie said, 'I don't know. ... [You said something about anger, is there something else besides your anger?] No, it’s my anger. I’ve got a really bad temper'.

\section{SUMMARY AND DISCUSSION}

Several key points framed my analysis of girls, peer violence, and restorative justice. First, the empirical literature on restorative justice does not give sufficient attention to the varied contexts of offending and victimisation that bring people to a conference process. The offence categories of 'violence' and 'property' do not accurately depict the entry points. 
From the SAJJ data, I identified seven offence types, which encapsulate victim-offender relations, the sex composition of the offence, and whether the victim was personal or organisational. Some kinds of offences cause victims more distress than others, both emotionally and physically; and when offenders justify or minimise their behaviour, a victim's distressed is increased. Thus, the ideal elements in a restorative process are variably achieved, depending on the offence, the offender's orientation, and the victim's distress. Of the seven offence types, the youth punch-ups displayed the widest gap in the aspirations and reality of restorative justice.

Second, the empirical literature on gender and restorative justice has given scant attention to offenders. If offenders are analysed, bi-variate gender comparisons may produce misleading findings on orientations to a restorative process (e.g., observed remorse, being defiant, wanting to make amends). Such analysis must take into account the offence dynamics that brought the offender and victim to the conference process. The 89 SAJJ conference observations showed that offending girls were more defiant, and less remorseful and apologetic than the boys, but this can be explained largely by the higher share of punch-ups in the girls’ offence structures. Researchers must also exercise caution in conducting bi-variate gender comparisons of victims, who also have different orientations to the conference process, depending on the character and dynamics of the offence.

One limitation of my study is the number of cases available to analyse genderbased variation in offender and victim orientations across a range of offences, not just punch-ups. Thus, I am not able to fully address the concerns raised by Alder (2000) that offending girls may appear more recalcitrant, less remorseful, and more 'difficult' to adult authorities; or that 'the community' may expect a greater degree of conformity from girls than boys. 
Third, the literature on girls' (and youths') peer violence shows that offenders justify their actions as provoked by things the victims said or did (or alleged to have said or done), to prevent victimisation, or to stick up for themselves (e.g., Burman, 2004; Miller \& Mullins, 2006). The SAJJ cases confirm this pattern. However, contrary to the claims of Artz (2004) and others, in just one of the girls’ fights (Britney and Patsy, case 59) were boys mentioned, although unspecified rumours were mentioned in two others. Unlike the US literature (Lockwood, 1997), none of the SAJJ fights involved knives or other weapons. Although studies of peer violence, both feminist and otherwise, suggest that offenders view violence as a rational response to perceived threats or insults, the literature is silent on how an offender's actions affect a victim. The literature is also silent on what an appropriate justice response could be for punch-ups. I turn to each of these areas.

\section{Offenders or Victims?}

The girls/women, crime, and victimisation literature is often bifurcated: some analysts focus on offending girls or women; and others, victimised girls or women. The two can be intertwined when authors situate girls’ offending in a broader context of their victimisation and sexual harassment by family members and boys, or their social and economic disadvantage (e.g., Artz, 2004; Gaarder \& Presser, 2006). However, when girls are victims of violence by girls, the blurred boundaries of victimisation and criminalisation shift in meaning: both protagonists claim a 'victim' (or 'non-offender') status. What are feminist analysts to make of these girls' stories and 'voices'?

In the SAJJ punch-ups, all the offending girls believed that the victims provoked the fight and deserved to be hurt. However, three of the nine were, in my judgment, more 'offenders' than 'victims': they continued to harass the victim (Olivia in case 48) and were ready to fight with little provocation (Moira in case 17 and Terry in case 82). In five other cases, there was a history of conflict between the girls; and it was difficult to discern the 
balance of offending and victimisation over time. Although culpability was unclear, three seemed tipped more toward 'offenders' than 'victims' (Susan in case 61, Liz in case 81, Samantha in case 4, not described in detail, see endnote 9); and two, more toward 'victims' than 'offenders' (Roxanne in case 87, Jackie in case 86). The ninth was the only case of immediate retaliation by an offender who believed she had to defend her sexual reputation (Britney in case 59).

Reading cases of girls' violence from the perspective of girls who are hurt by violence gives us a different, and more holistic, view of girls' fights. These offences caused the victims emotional or physical distress, or both. In three cases, the female victims remained traumatised or had physical scars. In punch-up cases, where the 'facts' of assaults are contested, where the stories of what happened and why diverge, analysts must give attention to the stories of those who were hurt and harmed. Otherwise, the literature will be littered with one-sided accounts of why violence was justified to protect one’s reputation.

\section{Whither Justice?}

What is an appropriate justice response in cases like these, and should restorative processes be used? My analysis finds that contrary to the positive results reported in the practice literature for male and female assault cases (e.g., Crosland \& Liebman, 2003: cases 4, 7, 9, $19,20,27,28)$, in no more than one-third of boys' or girls’ punch-ups was there a semiresolution of the conflict between the protagonists. Such a semi-resolution may be the most we can expect from a conference process. We should not expect the protagonists to become closer or best friends, but we might expect that the conflict does not escalate and there is an agreed truce. Contrary to the hopes of Gaarder and Presser (2006), positive dialogue, reconnection, and compassion by and between girls were atypical. Nor was there a conference discussion of the histories of violence between the two girls (when relevant). 
In this South Australia conference process, there was little discussion of the offending girls' histories of victimisation or family problems. Departing from Gaarder and Presser's views (2006), I believe that such discussions in punch-up cases would re-victimise victims; they are more properly part of professional counselling, not a justice encounter (see also Trankle, 2007). At the same time, had these cases gone to court, no dialogue or semiresolution between the girls would have occurred at all.

It is important to recall that each offending girl made admissions to the police that she had assaulted another girl. Despite this, few were ready to admit at the conference that what they did was wrong. Although several conferences were affected by poor practice by the coordinator and police officer, even the best-run conference will face impediments in punch-up cases. Not only must there be a full and frank discussion of culpability (which may be shared), but also the protagonists must desire to get along in the future, if only in a 'sort of' way. Frank discussions of culpability were difficult for the girls for many reasons, including not being able to explain their aggression or not wanting to permit adults (especially parents) into the secrets of their adolescent world. Getting along in the future was not a priority for most. The ethical practice of restorative justice for these cases may require a good deal more preparation and groundwork than many have assumed. Face-to-face meetings should not take place when offenders and victims contest 'facts', and offenders have little interest in making amends or in changing their behaviour. This produces a damaging dynamic that brings more suffering to those injured. The potential for this dynamic is not confined to partner or sexual violence cases, as many have assumed. The SAJJ project finds that it is evident in girls' and boys’ punch-ups. 


\section{ENDNOTES}

${ }^{1}$ I acknowledge the cooperation and in-kind assistance of the South Australian Family Conference Team, the South Australian Police, and the South Australian Courts Administration Authority. Without the support of these organisations and staff, this research could not have gone forward. The dedicated members of the research team and their roles are acknowledged in endnote 5. An Australian Research Council grant supported the data gathering (1998-99) phase of the research, with subsequent research assistance provided, in part, by the Key Centre for Ethics, Law, Justice, and Governance, Griffith University.

${ }^{2}$ The measures of restorativeness include the degree to which the offender was remorseful and understood the impact of the crime on the victim; the degree to which victims understood the offender's situation; and the extent of positive movement between the offender, victim, or their supporters, among other measures. Measures for fairness (or procedural justice) included perceptions of being treated fairly, with respect, and being listened to, among other measures.

${ }^{3}$ I exclude the literature on school bullying because it focuses on one type of child or youth aggression. Those who have applied restorative justice to school-based bullying programs have focused principally on the dynamics of re-integrative shaming (e.g., Ahmed et al., 2001; Morrison, 2002), which is not my focus.

${ }^{4}$ I exclude the many studies and reviews of studies on re-offending; see Bonta et al. (2006) and Hayes (2007) for overviews. 
5 The two SAJJ Technical Reports (Daly et al., 1998; Daly, 2001b) detail the ways in which I conceptualised gender, race, class, and age relations as power dynamics in the conference process; and how the researchers were asked to record such dynamics and to reflect on their feelings after observing the conference and interviewing the victims in 1998 and 1999. The two reports discuss the project's methods, survey and observation instruments, and interview schedules in depth. I am grateful to my research team who worked with me to construct the instruments, observe the 89 conferences, and conduct a total of 181 offender and 152 victim interviews in 1998 and 1999: Michele Venables (9899), Liz Mumford (98-99), Mary McKenna (98), Jane Christie-Johnston (98), and Rachel Mann (99). Brigitte Bouhours assisted in data cleaning, analysis, and codebook preparation during 2000 to 2003. All the face-to-face interviews were audio-recorded, except for a few participants who did not want this. Phone interviews were conducted with victims who did not attend the conference (26 percent of cases). All the open-ended portions of the interviews were transcribed for qualitative analysis. In presenting the quoted material, words in square brackets are those of the interviewer, when making probes or asking follow-up questions.

${ }^{6}$ For the non-punch-up cases, male and female victims' experiences of the conference process are part of another ms. in progress.

${ }^{7}$ The measure of 'victim distress' is described more fully in Daly (2005: 159).

${ }^{8}$ These incident 'facts' are drawn from the police report and may be supplemented from other observational or interview material on the file. 'The facts' are selectively constructed and often contested. The case number following is the unique identifier for each of the 89 conferences. All names used are pseudonyms. 
${ }^{9}$ The incident dynamics of the third case (case 4) were similar to the cases of on-going conflicts between the girls, who were not friends and did not like each other. Case 4 involved two non-Aboriginal girls; the offender (Samantha), victim (Rosie), and their mothers attended the conference; the mothers seemed to connect when agreeing that their daughters had 'a mouth', and the girls apologised outside the conference room. The longer term effect of the conference was of a semi-resolution, as in cases 61 and 81

10 This means an offender is to be of 'good behaviour' for a specified period of time; if s/he gets into trouble during this period, they face court charges. This was a more frequent outcome in the country town conferences than in Adelaide.

${ }^{11}$ Both conferences were organised and run by an Aboriginal coordinator.

\section{REFERENCES}

Ahmed, E., Harris, N., Braithwaite, J., \& Braithwaite, V. (2001). Shame management through reintegration. Cambridge: Cambridge University Press.

Alder, C. (2000). Young women offenders and the challenge for restorative justice. In H. Strang \& J. Braithwaite (Eds.), Restorative justice: Philosophy to practice (pp. 105120). Aldershot: Ashgate.

Alder, C., \& Worrall, A. (Eds.) (2004). Girls'violence: Myths and realities. Albany: State University of New York Press.

Artz, S. (2004). Violence in the schoolyard: School girls' use of violence. In C. Alder \& A. Worrall (Eds.), Girls’ violence: Myths and realities (pp. 151-166). Albany: State University of New York Press. 
Baines, M., \& Alder, C. (1996). Are girls more difficult to work with? Youth worker’s perspectives in juvenile justice and related areas. Crime and Delinquency, 42, 467485.

Bonta, J., Jesseman, R., Rugge, T., \& Cormier, R. (2006). Restorative justice and recidivism: Promises made, promises kept? In D. Sullivan \& L. Tifft (Eds.), Handbook of restorative justice: A global perspective (pp. 108-120). Abington: Routledge.

Burman, M. (2004). Turbulent talk: Girls’ making sense of violence. In C. Alder \& A. Worrall (Eds.), Girls’ violence: Myths and realities (pp. 81-103). Albany: State University of New York Press.

Cook, K. J., Daly, K., \& Stubbs, J. (Eds.) (2006). Theoretical Criminology, 10(1), Special issue on Gender, Race, and Restorative Justice.

Crosland, P., \& Liebman, M. (2003). 40 cases: Restorative justice and victim-offender mediation. Bristol: Mediation UK.

Daly, K. (1996). Diversionary conferencing in Australia: A reply to the optimists and skeptics. Paper presented at the American Society of Criminology Annual Meeting, Chicago, November.

Daly, K. (2001a). Conferencing in Australia and New Zealand: Variations, research findings, and prospects. In A. Morris \& G. Maxwell (Eds.), Restorative justice for juveniles: Conferencing, mediation and circles (pp. 59-83). Oxford: Hart Publishing. Daly, K. (2001b) South Australia Juvenile Justice (SAJJ) research on conferencing, technical report No. 2: Research instruments in year 2 (1999) and background notes. Brisbane: School of Criminology and Criminal Justice, Griffith University. Available at <http://www.griffith.edu.au/school/ccj/kdaly.html $>$

Daly, K. (2002a). Restorative justice: The real story. Punishment \& Society, 4(1), 55-79. 
Daly, K. (2002b). Widening the feminist lens on restorative justice. Paper presented at the American Society of Criminology Annual Meeting, Chicago, November.

Daly, K. (2003). Mind the gap: Restorative justice in theory and practice. In A. von Hirsch, J. Roberts, A. E. Bottoms, K. Roach, \& M. Schiff (Eds.), Restorative justice and criminal justice: Competing or reconcilable paradigms? (pp. 221-236). Oxford: Hart Publishing.

Daly, K. (2005). A tale of two studies: Restorative justice from a victim’s perspective. In E. Elliott \& R. Gordon (Eds.), New directions in restorative justice (pp. 153-174). Cullompton: Willan.

Daly, K. (2006). The limits of restorative justice. In D. Sullivan \& L. Tifft (Eds.), Handbook of restorative justice: A global perspective (pp. 134-145). Abington: Routledge.

Daly, K., \& Hayes, H. (2002). Restorative justice and conferencing. In A. Graycar \& P. Grabosky (Eds.), Handbook of Australian criminology (pp. 294-312). Cambridge: Cambridge University Press.

Daly, K., \& Stubbs, J. (2006). Feminist engagement with restorative justice. Theoretical Criminology, 10(1), 9-28.

Daly, K., Venables, M., Mumford, L., McKenna, M., \& Christie-Johnston, J. (1998). SAJJ technical report No. 1: Project overview and research instruments. Brisbane: School of Criminology and Criminal Justice, Griffith University. Available at $<$ http://www.gu.edu.au/school/ccj/kdaly.html>

Dignan, J. (2006). Juvenile justice, criminal courts and restorative justice. In G. Johnstone \& D. Van Ness (Eds.), Handbook of restorative justice (pp. 269-291). Cullompton: Willan. 
Gaarder, E., \& Presser, L. (2006). A feminist vision of justice? The problems and possibilities of restorative justice for girls and women. In D. Sullivan \& L. Tifft (Eds.), Handbook of restorative justice: A global perspective (pp. 483-494). Abington: Routledge.

Gilligan, C. (1982). In a different voice. Cambridge: Harvard University Press. Hayes, H. (2007). Reoffending and restorative justice. In G. Johnstone \& D. Van Ness (Eds.), Handbook of restorative justice (pp. 426-444). Cullompton: Willan. Johnstone, G., \& Van Ness, D. (Eds.) (2007). Handbook of restorative justice. Cullompton: Willan.

Kruttschnitt, C., \& Carbone-Lopez, K. (2006). Moving beyond the stereotypes: Women’s subjective accounts of their violent crime. Criminology, 44(2), 321-352.

Lockwood, D. (1997). Violence among middle school and high school students: Analysis and implications for prevention. National Institute of Justice Research in Brief, October.

Masters, G., \& Smith, D. (1998). Portia and Persephone revisited: Thinking about feeling in criminal justice. Theoretical Criminology, 2(1), 5-27.

Maxwell, G., Kingi, V., Robertson, J., Morris, A., \& Cunningham, C. (2004). Achieving effective outcomes in youth justice: Final report. Wellington: Ministry of Social Development.

Maxwell, G., \& Morris, A. (1993). Family, victims and culture: Youth justice in New Zealand. Wellington: Social Policy Agency and the Institute of Criminology, Victoria University of Wellington.

Maxwell, G., Morris, A., \& Hayes, H. (2006). Conferencing and restorative justice. In D. Sullivan \& L. Tifft (Eds.), Handbook of restorative justice: A global perspective (pp. 91-107). Abington: Routledge. 
McCold, P. (2006). The recent history of restorative justice: Mediation, circles, and conferencing. In D. Sullivan \& L. Tifft (Eds.), Handbook of restorative justice: A global perspective (pp. 23-51). Abington: Routledge.

Miller, J., \& Mullins, C. W. (2006). Stuck up, telling lies, and talking too much: The gendered context of young women’s violence. In K. Heimer \& C. Kruttschnitt (Eds.), Gender and crime: Patterns in victimization and offending (pp. 41-66). New York: New York University Press.

Morris, A., \& Maxwell, G. (Eds.) (2001). Restorative justice for juveniles: Conferencing, mediation and circles. Oxford: Hart Publishing.

Morrison, B. (2002). Bullying and victimisation in schools: A restorative justice approach. Trends \& Issues in Crime and Criminal Justice, 219, 1-6.

Retzinger, S., \& Scheff, T. (1996). Strategy for community conferences: Emotions and social bonds. In B. Galaway \& J. Hudson (Eds.), Restorative justice: International perspectives (pp. 315-336). Monsey: Criminal Justice Press.

Strang, H. (2001). Justice for victims of young offenders: The centrality of emotional harm and restoration. In A. Morris \& G. Maxwell (Eds.), Restorative justice for juveniles: Conferencing, mediation and circles (pp. 183-193). Oxford: Hart Publishing.

Strang, H. (2002). Repair or revenge: Victims and restorative justice. Oxford: Clarendon Press.

Strang, H., \& Braithwaite, J. (Eds.) (2002). Restorative justice and family violence. Cambridge: Cambridge University Press.

Sullivan, D. \& Tifft, L. (Eds.) (2006). Handbook of restorative justice: A global perspective. Abington: Routledge. 
Trankle, S. (2007). In the shadow of penal law: Victim-offender mediation in Germany and France. Punishment \& Society, 9(4), 395-415.

von Hirsch, A., Roberts, J., Bottoms, A. E., Roach, K., \& Schiff, M. (Eds.) (2003).

Restorative justice and criminal justice: Competing or reconcilable paradigms?

Oxford: Hart Publishing. 